\title{
PHÂN TÍCH ĐĂC ĐIỂM LÂM SÀNG, HÌNH ẢNH NộI SOI VÀ MÔ BỆHH HỌC Ở BẾNH NHÂN UNG THƯ DẠ DÀY TRẺ TUỔI
}

\author{
Vũ Trường Khanh ${ }^{1}$, Đào Trần Tiến ${ }^{1}$, Nguyễn Quý Linh ${ }^{2}$, \\ Trần Vân Khánh ${ }^{2}$, Trần Huy Thịnh ${ }^{2}$, Phí Thị Thùy Ngân ${ }^{1}$, Nguyễn Công Long ${ }^{1}$
}

TÓM TẮT.

Ung thư da dày có xu hướng tăng theo tuổi, hay gặp ở người lớn tuổi, ít gặp ở người trẻ tuổi. Mục tiều: Phân tích đặc điểm lẩm sàng, hình ảnh nội soi và mô bệnh học ung thư dạ dày ở người trẻ tuổi. Đối tượng \& phương pháp nghiên cứu: Nghiên cứu mô tả cắt ngang ở bệnh nhân ung thư da dày $\leq 40$ tuổi tại khoa Tiều hóa, Bệnh viện Bạch Mai từ tháng 7/2019 đến tháng 7/2020. Bênh nhân được thu thâp đặc điểm lâm sàng, hình ảnh nội soi dạ dày, mô bệnh hoc, và đánh giá đôt biến gen $\mathrm{CDH} 1$. Kết quả: 30 bệnh nhân ung thư dạ dày, tuổi trung bình 34,93 (21 40 tuổi) tỷ lề nứ/nam là 1,5. Đối tượng ung thư tư 35 - 40 tuổi có 21 bệnh nhân, chiếm 70\%. Tỉ lệ đột biến gen $\mathrm{CDH} 1$ là $50 \%$. Có $3 / 30(10 \%)$ bênh nhẩn có tiền sử gia đình bị ung thư dạ dày. Các triệu chứng lâm sàng hay gặp là: đau thượng vị $(90 \%)$, chướng bụng $(66,7 \%)$, chán ăn/đầy hơi/chậm tiêu (40\%). Tổng số $80 \%$ tôn thương ung thư có dang loét thâm nhiếm (Borman II, III), có 1 bệnh nhân ung thư thể lan tỏa (3,3\%). Trên mô bệnh học, 73,6\% bệnh nhân là ung thư da dày thuộc týp lan tỏa và $26,4 \%$ là týp ruột kém biệt hóa. Kết luận: Ung thư da dày ở người trẻ tuổi hay gặp ở nữ giới hơn nam giới, chủ yểu là týp lan tỏa, có liên quan tới tiền sử gia đình bị ung thư da dày.

Tư khóa: ung thư dạ dày trẻ tuổi, đặc điểm lâm sàng, nội soi, mô bệnh học, gen CDH1.

\section{SUMMARY}

ANALYSIS OF ENDOSCOPIC AND CLINICOPATHOLOGICAL CHARACTERISTICS OF GASTRIC CANCER IN YOUNG PATIENTS

Gastric cancer is more common in older patients, less observed in young patients. Aims: This study aimed at analyzing the endoscopic and clinicopathological characteristics of gastric cancer in young patients. Methods: We employed crosssectional design with all young patients with gastric cancer in the Department of Gastroenterology and Hepatology, Bach Mai Hospital from July 2019 to July 2020. All patients were asked about clinical symptoms, and their gastroscopy images, histopathology results and CHD1 genetic mutation test results were collected. Results: Totally 30 patients were enrolled into the study with the average age of 34.93 (from 21-40 years old), female/male ratio was 1.5 . There

${ }^{1}$ Trung tâm Tiêu hóa - Gan mật, Bệnh viện Bạch Mai

${ }^{2}$ Trường Đại học Y Hà Nội

Chịu trách nhiệm chính: Vũ Trường Khanh

Email: vtruongkhanh@gmail.com

Ngày nhận bài: 19.2.2021

Ngày phản biên khoa học: 30.3.2021

Ngày duyệt bài: 12.4.2021 were 21 patients from 35 to 40 years old, accounting for $70 \%$. The $\mathrm{CDH} 1$ genetic mutation rate was $50 \%$, and $3 / 10$ patients $(10 \%)$ had family history of gastric cancer. The most common clinical symptoms were epigastric pain (90\%), abdominal distension (66.7\%), loss of appetite/flatulence/dyspepsia (40\%). Of all patients, $80 \%$ had cancer lesions of infiltrative ulcer (Borrmann type II, III), one patient had diffuse gastric carcinoma. Regarding histopathology, $73.6 \%$ had gastric cancer with diffuse type, and $26.4 \%$ had intestinal-type poorly differentiated gastric cancer. Conclusions: Gastric cancer in young patients is more common in female than male, mainly with the diffuse type, and associated with family history of gastric cancer.

Keywords: gastric cancer in young patients, clinical symptoms, gastroscopy, histopathology, $\mathrm{CDH} 1$ genetic mutation.

\section{I. ĐĂT VẤN ĐỀ}

Ung thư da dày là 1 trong 5 loại ung thư hay gặp trên thế giới và theo Globocan 2020 có tỉ lệ tử vong đứng hàng thứ 3 (1). Ung thư da dày tăng theo tuổi, với tuổi hay gặp là trên 60 tuổi và người già (2). Ung thư dạ dày ở người trẻ tuổi được xác định khi xuất hiện ung thư ở người từ 40 tuổi trở xuống, chỉ chiếm $2-8 \%$ số trường hợp ung thư dạ dày $(2,3)$. Nói chung, ung thư dạ dày ở người trẻ tuổi điển hình hay gặp ở nữ giới và týp ung thư lan tỏa (4-6). Ung thư da dày ở người trẻ tuổi còn hay gặp ở người có tiền sử gia đình huyết thống bậc I bị ung thư dạ dày (2). Nguyên nhân của ung thư da dày là rất phức tạp. Một số nghiên cứu cho thây đột biến gen $\mathrm{CDH} 1$ đóng góp vào nguyên nhân gầy ung thư dạ dày ở người trẻ tuổi. Chính vì ung thư dạ dày ở người trẻ tuổi ít gặp nên trong nghiên cứu này chúng tôi tập trung phân tích đặc điểm lâm sàng, hình ảnh nội soi và mô bệnh học của ung thư dạ dày ở người $\leq 40$ tuổi.

\section{II. ĐỐI TƯỢNG VÀ PHƯƠNG PHÁP NGHIÊN CỨU}

Đây là một nghiên cứu tiến cứu mô tả cắt ngang trong khoảng thời gian từ tháng 7/2019 đến tháng 7/2020.

Đối tượng là 30 bệnh nhân được chẩn đoán ung thư biểu mô tuyến dạ dày với tuổi $\leq 40$. Bênh nhân đồng ý tham gia nghiên cứu. Bênh nhân được hỏi bệnh, thăm khám, hỏi về tiền sử huyết thống bậc İ có ung thư dạ dày hay không. Người bệnh được tiến hành nội soi dạ dày trên 
hệ thống máy nội soi Fujifilm BL 7000 hoặc EPX 4450 với dây nội soi 600 và 760 tại khoa Tiêu hóa, Bệnh viện Bạch Mai (nay là trung tâm Tiêu hóa - Gan mât), đánh giá kết quả trên nọi soi, mô bệnh học của ung thư dạ dày. Bệnh nhân được lấy máu tách chiết DNA sử dụng kỹ thuật khuếch đại gen bằng kỹ thuật $\mathrm{PCR}$ để xác định đột biến gen CDH1.

Xử lý số liệu: Số liệu được xử lý trên phần mềm Epidata 7.0 và phần mềm xử lý thống kê SPSS 25.0.

Bệnh nhân tự nguyện đồng ý tham gia nghiền cứu và được xét nghiệm xác định đột biến gen $\mathrm{CDH} 1$ không mất tiền.

\section{KẾT QUẢ NGHIÊN CỨU}

Bảng 1. Đặc điểm chung của đối tượng nghiên cứu

\begin{tabular}{|c|c|c|}
\hline \multicolumn{2}{|c|}{ Đắc điếm } & $\mathbf{n ~ ( \% )}$ \\
\hline \multirow{2}{*}{ Giới } & Nam & $18(60 \%)$ \\
\cline { 2 - 3 } & Nữ & $12(40 \%)$ \\
\hline \multicolumn{2}{|c|}{ Tuối trung bình } & $34,93(21-40)$ \\
\hline $\begin{array}{c}\text { Tiền sư gia đình ung thư } \\
\text { dạ dày }\end{array}$ & $3(10 \%)$ \\
\hline \multicolumn{2}{|c|}{ Đột biến gen CDH1 } & $15(50 \%)$ \\
\hline \multicolumn{2}{|c|}{ Trong số 30 bệnh nhân ung thư dạ dày ở }
\end{tabular}

người $\leq 40$ tuổi, tỷ lệ nữ/nam là $18 / 12=1,5$. Tuổi trung bình là 34,93 , trong đó người trẻ nhất là 21 tuổi. Ung thư da dày từ độ tuổi 35 - 40 tuổi có 21 bệnh nhân, chiếm $70 \%$. Tỉ lệ đột biến gen $\mathrm{CDH} 1$ là $50 \%$.

Bảng 2. Thời gian bị bệnh trước thời điểm chẩn đoán

\begin{tabular}{|c|c|c|}
\hline Thời gian bị bệnh & Tân số (n) & Tỷ lệ \\
\hline$\leq 3$ tháng & 5 & $16,7 \%$ \\
\hline 3 đến 6 tháng & 17 & $56,7 \%$ \\
\hline 6 đến 9 tháng & 6 & $20 \%$ \\
\hline$\geq 9$ tháng & 2 & $6,6 \%$ \\
\hline
\end{tabular}

Phần lớn bệnh nhân được chấn đoán sau khi xuất hiện triệu chứng lâm sàng từ 3 - 9 tháng, chiếm 76,7\%.

Bảng 3. Một số triệu chứng lâm sàng

\begin{tabular}{|c|c|c|}
\hline $\begin{array}{c}\text { Một số triệu chứng lâm } \\
\text { sàng }\end{array}$ & $\begin{array}{c}\text { Tân số } \\
\text { (n) }\end{array}$ & Tỷ lệ \\
\hline Đau thượng vị & 27 & $90 \%$ \\
\hline Nôn máu đại tiện phân đen & 2 & $6,7 \%$ \\
\hline Nôn thức ăn cũ & 5 & $16,7 \%$ \\
\hline Sờ thấy u thượng vị & 1 & $3,3 \%$ \\
\hline Thiếu máu & 4 & $13,3 \%$ \\
\hline Chướng bụng & 20 & $66,7 \%$ \\
\hline Chán ăn đầy hơi chậm tiêu & 12 & $40 \%$ \\
\hline
\end{tabular}

Trong số các triệu chứng lâm sàng, triêu chứng đau vùng thượng vị, chướng bụng, chán ăn đầy hơi chậm tiêu là hay gặp nhất với tỷ lệ lần lượt là $90 \%, 66,7 \%$ và $40 \%$. Các triệu chứng thiếu máu, nôn thức ăn cũ và nôn máu ít gặp hơn chiếm tỷ lệ lần lượt là $13,3 \%, 16,7 \%$ và $6,7 \%$.

Bảng 4. Vị trí ung thư trên nội soi

\begin{tabular}{|c|c|c|}
\hline Vị trí u & $\begin{array}{c}\text { Số bệnh nhân } \\
(\mathbf{n = 3 0 )}\end{array}$ & Tỷ lệ \\
\hline Tâm vị & 2 & $6,7 \%$ \\
\hline Vị trí khác: & 28 & $93,3 \%$ \\
Thân vị & 12 & $40 \%$ \\
Hanng vị & 15 & $50 \%$ \\
Toàn bộ dạ dày & 1 & $3,3 \%$ \\
\hline
\end{tabular}

Ung thư ở vị trí tâm vị ít gắp chỉ chiếm $6,7 \%$. Đa phần tổn thương ung thư không thuộc vùng tâm vị, vị trí hang vị hay gặp chiếm $50 \%$.

Bảng 5. Hinh thái dại thể trên nội soi theo phân loại Bormann

\begin{tabular}{|c|c|c|}
\hline & $\begin{array}{c}\text { Số bệnh nhân } \\
(\mathbf{n}=\mathbf{3 0})\end{array}$ & Tỷ lệ \\
\hline Týp I & 5 & $16,7 \%$ \\
\hline Týp II & 10 & $33,3 \%$ \\
\hline Týp III & 14 & $46,7 \%$ \\
\hline Týp IV & 1 & $3,3 \%$ \\
\hline
\end{tabular}

Phần lớn u có dang loét thâm nhiếm chiếm $80 \%$ các trường hợp, chỉ có 1 bệnh nhân ung thư thể lan tỏa chiếm 3,3\%.

Bảng 6. Kêt quả mô bệnh học

\begin{tabular}{|c|c|c|}
\hline $\begin{array}{c}\text { Týp mô bệnh } \\
\text { học }\end{array}$ & $\begin{array}{c}\text { Số bệnh nhân } \\
\text { (n= 30) }\end{array}$ & Tỷ lệ \\
\hline $\begin{array}{c}\text { Týp ruột biệt hóa } \\
\text { kém }\end{array}$ & 8 & $26,7 \%$ \\
\hline Týp lan tỏa & 22 & $73,3 \%$ \\
\hline Týp hôn hợp & 0 & $0 \%$ \\
\hline
\end{tabular}

Tất cả bệnh nhân đều thuộc týp lan tỏa hoặc týp ruột kém biệt hóa.

\section{BÀN LUẬN}

Ung thư dạ dày ở người trẻ tuổi trong nghiên cứu của chúng tôi có tới $70 \%$ là từ tuổi $35-40$, người trẻ nhất là 21 tuổi. Theo nghiên cứu của Moon H.H. khi nội soi tình cờ phát hiện được 84 bệnh nhân ung thư dạ dày ở người trẻ tuổi, tuổi 35 - 39 chiếm $57 \%$, người trẻ nhất là 21 tuổi (7). Tại Nhật Bản trong nghiên cứu của Kunisaki C. với 131 bệnh nhân ung thư dạ dày ở người trẻ tuổi thì $63,3 \%$ tuổi từ $35-40$ (8). Nghiên cứu tại Mỹ năm 2000 của Koea J.B. với 92 bệnh nhân ung thư dạ dày ở người trẻ tuổi, có $51,2 \%$ tuổi từ 35 - 40 (9). Như vậy, nói chung ung thư da dày ở người trẻ tuổi thường gặp từ 35 - 40 tuổi, mặc dù có thể gặp ở người rất trẻ chỉ 21 tuổi.

Theo Ławniczak $M$. ung thư da dày thường gặp ở nam nhiều hơn nữ, với 775 bệnh nhân ung thư dạ dày trên 40 tuổi thì tỉ lệ nam/nữ là $2,1 / 1$. Trong các nghiên cứu khác, ung thư da dày ở người trẻ tuổi với 65 bệnh nhân thì tỉ lệ 
nam/nữ là $0,7 / 1$ (2). Tương tự như vây tại Hàn Quốc tác giả Chung HW công bố 1850 bệnh nhân ung thư dạ dày ở người trẻ tuổi, tî̉ lệ nam/nữ là $0,75 / 1$ (6). Mắc dù người ta chưa hiểu rõ tại sao ung thư da dày ở người trẻ tuổi lại hay gặp hơn ở nữ so với nam, nhưng có những giải thích cho rằng ung thư dạ dày ở người trẻ tuổi có liên quan tới hormon sinh dục nữ.

Ung thư da dày ở người trẻ tuổi cũng liên quan tới yếu tố tiền sử gia đình bị ung thư dạ dày. Trong nghiên cứu này chúng tôi thấy có $3 / 30$ bệnh nhân $(10 \%)$ có tiền sử bố mẹ hoặc anh chị em ruột bị ung thư dạ dày, điều này có thể liên quan tới đột biến gen. Theo tác giả Chung HW (6), 7,8\% bệnh nhân ung thư dạ dày trẻ tuổi có tiền sử gia đình bị ung thư dạ dày. Trong nghiên cứu này 15/30 bệnh nhân có đột biến gene $\mathrm{CDH} 1(50 \%)$, trên thế giới các nghiền cứu cũng chỉ ra rằng 30 - 50\% ung thư da dày ở người trẻ tuổi có đột biến gene CDH1.

Trong nghiên cứu của chúng tôi có $56,7 \%$ số bệnh nhân được chẩn đoán ung thư dạ dày, có triệu chứng trước đó từ 3-6 tháng, chỉ có 16,7\% số bệnh nhân được chẩn đoán bệnh trong vòng 3 tháng kể từ khi có triệu chứng. Theo một số tác giả phần lớn bệnh nhân ung thư dạ dày ở người trẻ tuổi được chẩn đoán là sau nhiều tháng có triệu chứng, Koea JB cho thấy nhóm bệnh nhân của ông trung bình được phát hiện là sau 26 tuần kể từ khi có triệu chứng (9), sở dĩ vậy là do ở người trẻ tuổi ít được bác sỹ nghĩ tới nguy cơ ung thư dạ dày so với người lớn tuổi và thường người trẻ sẽ được điều trị thuốc trước đó, sau khi không đáp ứng hoặc đáp ứng không hoàn toàn mới được chỉ định nội soi dạ dày. Đau thượng vị, chướng bụng, chán ăn đầy hơi chậm tiêu hay gặp chiếm tỳ lệ lần lượt $90 \%, 66,7 \%$ và $40 \%$; có $16,7 \%$ bệnh nhân đã có biếu hiện hẹp môn vị, hầu như tất cả bệnh nhân khi đến nội soi là đã có triệu chứng trên lâm sàng, không có bệnh nhân nào tình cờ phát hiện ung thư dạ dày khi khám sức khỏe định kỳ.

Trên hình ảnh nội soi dạ dày chỉ có 2/30 bệnh nhân $(6,7 \%)$ ung thư nằm ở vị trí tâm vị, cững giống như các tác giả khác tỉ lệ ung thư dạ dày nằm $1 / 3$ trên là $9 \%$ theo tác giả Ławniczak $M$ (2). Cũng giống như ung thư dạ dày ở người lớn tuổi, ung thư dạ dày ở người trẻ tuổi chủ yếu gặp ở vùng hang vị và thân vị, ít gặp hơn ở vùng tâm vị. Tất cả bênh nhân khi phát hiên ung thư trên nội soi trong nghiên cứu này bệnh đã ở giai đoạn tiến triển, $80 \%$ là thể sùi và loét tương ứng với Bormann II và III, chỉ có $1 / 30$ trường hợp $(3,3 \%)$ là thể thâm nhiễm lan tỏa.
Trong nghiên cứu này chúng tôi thây rằng 22/30 (73,6\%) bệnh nhân trên mô bệnh học là ung thư dạ dày thuộc týp lan tỏa và $6 / 30$ $(26,4 \%)$ là týp ruột kém biệt hóa, kết quả này cũng tương tự như của tác giả Ławniczak $M$ với týp lan tỏa chiếm $73,6 \%$ (2) và theo Chung HW ở 1850 bệnh nhân ung thư dạ dày trẻ tuổi với $76,7 \%$ là týp lan tỏa (4-6).

\section{KẾT LUÂ̂N}

Trong nghiên cứu của chúng tôi thấy rằng ung thư dạ dày ở người trẻ tuổi có đặc điểm hay gặp hơn ở nữ giới so với nam giới, với tỉ lệ nữ/nam là $1,5 / 1$, chủ yếu là týp lan tỏa với $73,6 \%$ và có liên quan tới tiền sử gia đình bị ung thư dạ dày là $10 \%$.

\section{TÀI LIẸU THAM KHẢO}

1. Siegel RL, Miller KD, Jemal A. Cancer statistics, 2020. CA: a cancer journal for clinicians. 2020;70(1):7-30.

2. Ławniczak $M$, Gawin A, JaroszewiczHeigelmann H, Rogoza-Mateja W, Białek A, Kulig J, et al. Analysis of clinicopathologic characteristics of gastric cancer in patients $\leq 40$ and $\geq 40$ years of age. Scandinavian journal of gastroenterology. 2020;55(1):62-6.

3. Al-Refaie WB, Hu CY, Pisters PW, Chang GJ. Gastric adenocarcinoma in young patients: a population-based appraisal. Annals of surgical oncology. 2011;18(10):2800-7.

4. Bai Y, Li ZS. Endoscopic, clinicopathological features and prognosis of very young patients with gastric cancer. Journal of gastroenterology and hepatology. 2011;26(11):1626-9.

5. Park HJ, Ahn JY, Jung HY, Lim H, Lee JH, Choi KS, et al. Clinical characteristics and outcomes for gastric cancer patients aged $18-30$ years. Gastric cancer: official journal of the International Gastric Cancer Association and the Japanese Gastric Cancer Association. 2014;17(4):649-60.

6. Chung HW, Noh SH, Lim JB. Analysis of demographic characteristics in 3242 young age gastric cancer patients in Korea. World journal of gastroenterology. 2010;16(2):256-63.

7. Moon HH, Kang HW, Koh SJ, Kim JW, Shin CM. Clinicopathological Characteristics of Asymptomatic Young Patients with Gastric Cancer Detected during a Health Checkup. The Korean journal of gastroenterology = Taehan Sohwagi Hakhoe chi. 2019;74(5):281-90.

8. Kunisaki $C$, Akiyama $H$, Nomura $M$, Matsuda G, Otsuka Y, Ono HA, et al. Clinicopathological features of gastric carcinoma in younger and middle-aged patients: a comparative study. Journal of gastrointestinal surgery : official journal of the Society for Surgery of the Alimentary Tract. 2006;10(7):1023-32.

9. Koea JB, Karpeh MS, Brennan MF. Gastric cancer in young patients: demographic, clinicopathological, and prognostic factors in 92 patients. Annals of surgical oncology. 2000;7(5):346-51. 